\title{
Biodeterioration vs Biodegradation: the Role of Microorganisms in the Removal of Pollutants Deposited on Historic Buildings
}

\author{
C. Saiz-Jimenez \\ Instituto de Recurson Naturales y Agrohiologia. C.S.I.C. Apartado I052, 4l080 Sevilta, Spain
}

\begin{abstract}
This paper describes some biodegradation processes originating from the activity of microorganisms in the black crusts of historic buildings. The crusts are mainly composed of gypsum, carbonaceous particles, and polycyclic aromatic hydrocarbons. The slowly dissolving gypsum from black crusts represents a continuous source of sulphur for microbial growth. The sulphate-bonding capacity of the sheath of cyanobacteria causes a particularly high demand for sulphate, thus making sulphur nutrition a relevant aspect in their physiology. On the other hand, bacteria capable of using polycyclic aromatic hydrocarbons as a sole carbon and energy source were isolated from monuments. These examples illustrate that on the surfaces of building stones, located in polluted environments, there is a continuous deposition and, at the same time, a hiodegradation of pollutants leading to their removal.

Se describen algunos procesos de biodegradación estudiados en constra: negras de edificios históricos. Estas costras, formadas mayoritariamente por yeso. particulas carbonáceas e hidrocarburos policiclicos aromáticos, son, por una parte, una importante fuente de azufre, necesaria para la sintesis de los polisácaridos de las vainas de cianobacterias. Por otra, algunas bacterias utilizan los hidrocarburos policiclicos aromáticos como fuente de carbono : energia. Estos ejemplos indican que, junto a la deposición de contaminantes sobre la superficie de los monumentos, existe una variada actividad microbiana que conduce a su biodegradación y eliminación.
\end{abstract}

\section{INTRODUCTION}

Building materials exposed to open air deteriorate due to natural causes. Sun, frost, wind, rain, etc. contribute to a gradual process of weathering. Biological activity also plays a role, and its interaction with physico-chemical mechanisms is considered central to the understanding of longterm deterioration.

In the last decades, industrial and urban activities have modified the composition of the atmosphere, resulting in a more aggressive environment, accelerating the decay of materials. Sulphur dioxide is one of the major gaseous components of polluted atmospheres in urban areas. Because oxidation of sulphur dioxide results in the formation of sulphuric acid, there is a strong correlation between the sulphatation of limestones and the atmospheric concentration of sulphur dioxide. Sulphuric acid attacks limestones resulting in the formation of gypsum. During the crystallization of gypsum, airborne organic pollutants, carbonaceous particles, dust, pollen, etc. are accummulated at the surface of buildings and trapped in the mineral matrix. This results in the formation of a hard, grey to black crust (SaizJimenez, 1993). Obviously, this crust enriches the substratum and anthropogenic compounds may influence, to a great extent, the colonization and growth pattern of microorganisms in stones located in polluted environments when compared with the growth of microorganisms in similar stones placed in rural environments.

Although it has been reported that a great variety of microorganisms colonize stones in urban environments, and their possible role in the biodeterioration of stones is discussed (SaizJimenez, 1995), the interactions between anthropogenic compounds and microorganisms have barely been investigated. This paper focuses 
on some biodegradation processes caused by microorganisms colonizing building stones.

\section{INORGANIC AND ORGANIC COMPOSITION OF BLACK CRUSTS}

Although there is a consensus on the composition of black crusts in terms of gypsum and carbonaceous particles, investigation of the chemical nature of the (individual) organic compounds entrapped in the crusts has barely been carried out (Saiz-Jimenez, 1991, 1993). As a general characteristic, the black crusts from monuments sampled in different locations and countries present a diversity of organic compounds entrapped in the mineral matrices. This diversity is determined by the different nature of the aerosols and particulates present in the atmosphere of each location. However, black crusts obtained from different building materials in the same monument had similar composition (Saiz-Jimenez, 1993).

Del Monte et al. (1981) identified two types of particles in black crusts: spherical shape, irregular rough surface, and high porosity (assigned to oilfired combustion plants), and spherical shape with smooth surface (deriving from coal-fired combustion plants). Both types of particles have diameters of about $10 \mu \mathrm{m}$ and contain carbon, silicon. sulphur, aluminium, and calcium as major constituents.

Saiz-Jimenez and Bernier (1981) found that the black crusts of some Sevillian monuments were composed of gypsum, quartz, and aluminosilicates together with airborne carbonaceous particles derived from oil combustion. The carbonaceous particles are very sorptive, have high levels of organic matter, and exhibit high specific surface areas. Polycyclic aromatic hydrocarbons are strongly sorbed by and difficult to extract from particles because their matrices contain silica, alumina, metal oxides, and possibly even activated carbon, all of which are excellent adsorbents for organic compounds (Christwell et al., 1988).

The extractable lipid material of black crust samples consisted primarily of aliphatic hydrocarbons and fatty acids (as methyl esters), represented by homologous series of $n$-alkanes ranging from $\mathrm{C}_{8}$ to $\mathrm{C}_{32}$, and $n$-fatty acids from $\mathrm{C}_{4}$ to $\mathrm{C}_{30}$ (Table 1). Furthermore, diterpenoids, triterpanes, steranes, polycyclic aromatic hydrocarbons, and dialkyl phthalates were identified.

Polycyclic aromatic hydrocarbons are the result of combustion of biomass, coal and oil, and have been identified, among other sources, in smoke particles from plant burning (Standley and Simoneit, 1987) and diesel engine soot (Yu and Hites, 1981). Polycyclic aromatic hydrocarbon mixtures encountered in black crust are complex because of the presence of alkyl-substituted compounds, as well as the numerous isomeric parent compounds. Generally, compounds from two to six aromatic rings are widely distributed in black crusts from different European monuments. In addition, ketones, sulphur and nitrogensubstituted aromatic hydrocarbons were identified (Saiz-Jimenez, 1991, 1993).

Petroleum biomarkers are compounds utilized for defining both the fossil origin and the geological source of the petroleum residues (Simoneit et al., 1988). An example is the $17 \alpha(\mathrm{H}), 21 \beta(\mathrm{H})$-hopane series, from which a few homologues eluted with some of the major peaks in the black crusts. These compounds are widely distributed in urban aerosols, originating from lubricating oil in vehicular emissions. Interestingly, the pattern of hopanes from black crusts was similar to those reported for crude oil (Philp, 1985) and automobile and diesel engine exhausts (Simoneit, 1985).

It appears that exposed building materials act as non-selective surfaces, passively entrapping all deposited airborne particulate matter and organic

Table 1. Major Classes of Compounds Identified in Black Crusts

\begin{tabular}{|c|c|c|c|}
\hline Compounds & Range $^{a}$ & Compounds & Range \\
\hline Alkanes & $\mathrm{C}_{8}-\mathrm{C}_{32}$ & Diterpenoid hydrocarbons & $C_{18}-C_{20}$ \\
\hline Alkenes & $\mathrm{C}_{8}-\mathrm{C}_{32}$ & Triterpenoid hydrocarbons & $C_{27}-C_{35}^{20}$ \\
\hline Alkylbenzenes & $C_{1}-C_{20}$ & $\begin{array}{c}\text { Tricyclic terpane } \\
\text { hydrocarbons }\end{array}$ & $\mathrm{C}_{23}-\mathrm{C}_{29}$ \\
\hline Fatty acids & $C_{4}-C_{30}$ & Steranes and diasteranes & $\mathrm{C}_{2 T}-\mathrm{C}_{29}$ \\
\hline$\alpha, \omega$-Dicarboxylic acids & $\mathrm{C}_{4}-\mathrm{C}_{18}$ & $\begin{array}{c}\text { Polycyclic aromatic } \\
\text { hydrocarbons }\end{array}$ & $\mathrm{C}_{10}-\mathrm{C}_{18}^{-3}$ \\
\hline
\end{tabular}

"Range denotes number of carbon atoms in the compounds. 
compounds. Accordingly, the black crusts coating the surfaces of building materials located in polluted environments are constituted by a suite of all kinds of organic compounds present in aerosols and particulate matter. The study of molecular markers present in black crusts indicated that oil and coal combustion are the principal sources of pollutants (Saiz-Jimenez, 1993).

\section{MICROBIOLOGY OF THE BLACK CRUSTS}

Although in the literature many reports on the microbiology of weathered stones in monuments can be found, attention to the microflora of black crusts has barely been drawn, and only a few studies on the growth of epilithic phototrophic microorganisms on black crusts (Ortega-Calvo et al. 1993) and endolithic filamentous cyanobacterium (Phormidium sp.) under black crusts (Saiz-Jimenez et al., 1990; Saiz-Jimenez et al., 1991) can be found.

It has been suggested that the presence of an organism on decayed material does not necessarily imply that it has caused the damage observed (Saiz-Jimenez, 1995). The activity of microorganisms in promoting stone deterioration is largely dependent upon the production of corrosive metabolites which can solubilize minerals in a manner similar to chemical agencies. Probably, low-frequency isolation cannot be directly correlated with metabolic activity as, for instance, the fungi isolated in culture media may be dormant (spores) and are not necessarily the ones which are functioning in the ecosystem. Because isolation in culture media rich in organic carbon can mask the real fungal distribution in weathered stones and isolate selectively airborne propagules instead of active microorganisms, an approach involving direct study of gypsum crusts was carried out by Saiz-Jimenez (1993). The incubation of the crusts in Petri dishes with sterile water revealed a different fungal population to those previously reported by Petersen et al. (1988) and De la Torre et al. (1991) in weathered stones. In fact, from the Seville cathedral a Papulasporalike fungus with dark chlamydospore balls was the only isolate, with a high presence in the tested samples $(82 \%)$. From Mechelen cathedral the species isolated were Engyodontium album (15\%), Botriotrichum piluliferum (4\%), Ulocladium atrum $(4 \%)$, and Mucor circinelloides (4\%). These fungi most probably use the organic compounds present in the black crusts, which include, among others, aliphatic and aromatic hydrocarbons, fatty acids, triterpanes, etc. (Saiz-Jimenez, 1991). Therefore, it appears that two types of fungal populations can be isolated from stones: those utilizing readily available carbon (carbohydrates), which are similar to ubiquitous saprophytic airborne fungi, evidenced by using conventional culture media, and those using petroleum derivatives originating from the deposition of pollutants, which are probably present in a relatively minor part of the population utilizing carbohydrates.

Although ubiquitous in terrestrial and aquatic environments, the fraction of the total heterotrophic community represented by the hydrocarbon-utilizing bacteria and fungi is highly variable, with reported frequencies ranging from $6 \%$ to $82 \%$ for soil fungi and $0.13 \%$ to $50 \%$ for soil bacteria (Leahy and Colwell, 1990). Nyns et al. (1968) tested a wide range of fungi for their ability to assimilate aliphatic and aromatic hydrocarbons and petroleum fractions. Species of the genera Fusarium, Penicillium and Aspergillus are particularly active in the assimilation of hydrocarbons. Bossert and Bartha (1984) listed 22 genera of bacteria and 31 genera of fungi able to degrade hydrocarbons.

The most remarkable fact is that the list of genera of fungi growing on hydrocarbons reported by Nyns et al. (1968) or the most frequent isolates quoted by Leahy and Colwell (1990) agree well with those isolated from weathered building stones and frescoes (Saiz-Jimenez and Samson. 1981; Petersen et al., 1988; Karpovich-Tate and Rebrikova, 1990; De la Torre et al., 1991; SaizJimenez, 1993). This finding indicates a possible relationship between fungi and organic pollutants derived from oil combustion.

\section{BIODEGRADATION OF BLACK CRUSTS}

Although biodeterioration processes have been discussed by some authors (Petersen el al., 1988; Saiz-Jimenez et al., 1990; De la Torre et al., 1991; Ortega-Calvo et al., 1991; Warscheid et al., 1991), biodegradation of pollutants in monuments has barely been investigated. Recently, both biodegradation of gypsum crusts by cyanobacteria and polycyclic aromatic hydrocarbons by heterotrophic bacteria have been reported (Ariño et al., 1995; Ortega-Calvo and Saiz-Jimenez, 1996).

The presence of phototrophic microorganisms is 
more apparent on the north façades of buildings than on the south, because the latter dry out more readily. These organisms are also frequently found on black crusts where they form large patches of green, brown and black cyanobacterial/algal mats, giving an unaesthetical appearance to buildings. These patches largely consist of biofilms - cells and other materials immobilized on the substrata and embedded in an organic matrix. Biofilm may also contain significant amounts of adsorbed inorganic materials derived from the substratum (quartz, calcium carbonate, clay) and detritus (dead cells, microbial by-products, etc.). The slimy surface favours the adherence of airborne particles (dust, pollen, spores, oil- and coal-fired carbonaceous particles) giving rise to hard crusts and patinas which are difficult to eliminate (SaizJimenez, 1984).

The biofilms formed on black crusts are usually characterized by the abundant presence of Chroococcales (Gloeothece, Gloeocapsa, etc.). Gloeothece is a unicellular cyanobacterium capable of fixing nitrogen aerobically and producing a complex sheath with high amounts of sulphate (Tease et al., 1991).

Black crusts deposited in Petri dishes with only the addition of sterile water doubled the biomass in four weeks when inoculated with the cyanobacterium Gloeothece sp. The result shows that the mineral content of the crusts is enough to support cyanobacterial development. Observations of a wide range of monuments in different enviromental conditions indicate that black crusts covering building stones are colonized by phototrophic microorganisms (Ortega-Calvo ef al., 1991, Ortega-Calvo el al., 1993). The findings suggest that gypsum might play a role in the cyanobacterial colonization of blackened monuments in urban enviroments.

Under laboratory conditions it was proven that the gypsum present in a black crust from the cathedral of Seville. Spain, can be used as a source of sulphur by the cyanobacterium Gloeothece sp. (Ortega-Calvo et al., 1994). The sulphate released to the medium due to gypsum dissolution was progressively incorporated into the carbohydrate sheath and used for balanced growth (Fig. 1).

The sulphate-bonding capacity of the sheath in Gloeothece sp. causes a particularly high demand for this anion. This makes sulphur nutrition a relevant aspect in the physiology of this cyanobacterium, as demonstrated by Ariño et al. (1995). In fact, when deprived of sulphur, bleached Gloeothece sp. cells contain a disintegrated photosynthetic apparatus and accumulations of different kinds of reserve material. Such characteristics are absent in sulphate-sufficient diazotrophic cultures. The inability to obtain from the culture medium an adequate supply of sulphur for protein synthesis and, therefore, for balanced growth, induces in Gleoethece sp. the immobilization of fixed carbon in the form of glycogen, polyhydroxybutyrate, and cyanophycin. In other words, Gleoethece sp. reacts to sulphur starvation by notable changes in its ultrastructure related to alteration in the overall physiological processes, including sheath synthesis, nitrogen metabolism, and photosynthesis (Fig. 2). The addition of sulphate to a sulphate-defficient medium restored the regular activity of the cyanobacterium.

On the other hand, not only cyanobacteria grow

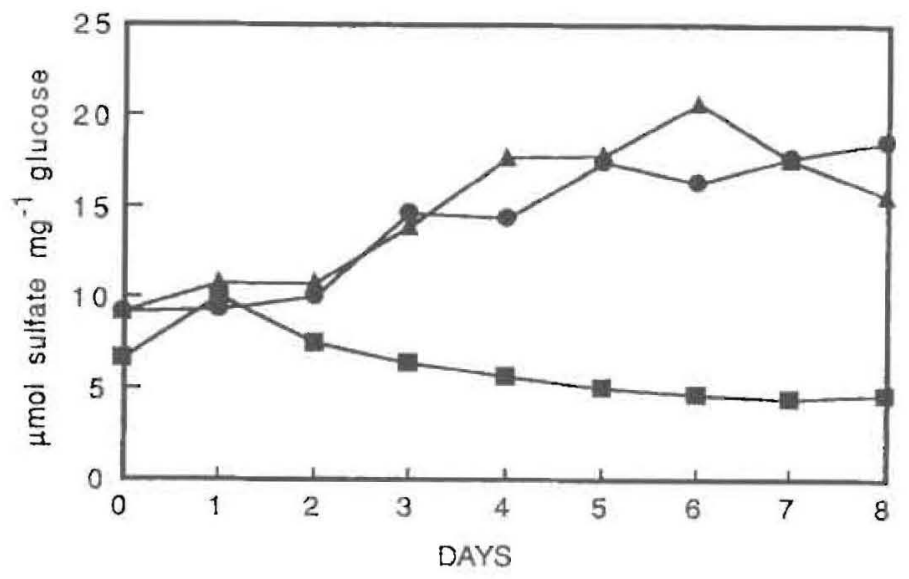

Fig. 1. Evolution of the sulphate content of sheath carbohydrate in cultures with gypsum from black crust $(\bullet)$, with magnesium sulphate $(\mathbf{A})$, and with no sulphur source (- 


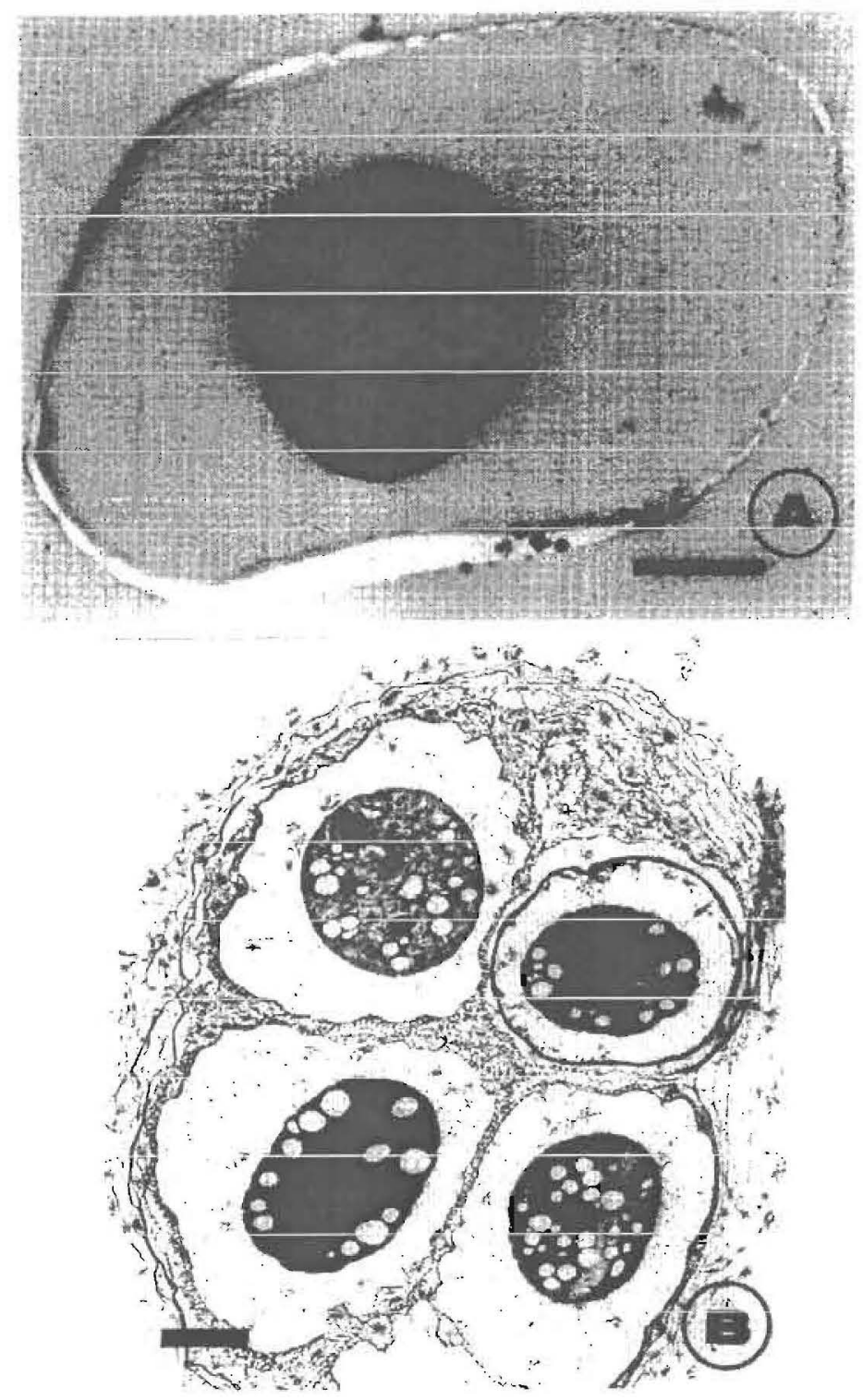

Fig. 2. TEM micrograph of Gloeorhece sp. (a) Cell grown with sulphate, with a perfect organization of thylakoids; (b) cell grown without sulphate, containing a high number of cyanophycin and PHB Granules. Bars: $2 \mu \mathrm{m}$.

on black crusts, but heterotrophic bacteria, able to use various organic compounds as a source of carbon and energy, can be found. Lewis et al. (1988) suggested that bacteria on stone can be extremely versatile and could maintain their activity during nutrient perturbations, operating at low nutrient levels and utilizing what the environment has to offer. As a consequence, bacterial populations may be able to maintain their involvement in the process of stone deterioration during periods of nutrient flux.

Warscheid et al. (1991) studied chemoorganotrophic bacteria from the uppermost layers of sandstones of German monuments. It was shown that most of the isolated bacteria used a wide range of different carbohydrates, amino acids, fatty acids, and hydrocarbons. About $40 \%$ of the strains were shown to be potential acid producers, whereas the capability of manganese and iron oxidation was only sporadically found. Kerosene, as a representative mixture of different hydrocarbons detectable in polluted atmospheres, was well metabolized by $70 \%$ of the bacteria.

It has been stressed that the degradation of petroleum by bacteria often results in the progressive depletion of chromatographically resolved hydrocarbons (e.g. n-alkanes, acyclic isoprenoid alkanes, alkylbenzenes, alkylnaphthalenes, and alkylphenanthrenes) relative to the unresolved hydrocarbon mixture (UCM). Hence, 
the UCM is thought to comprise compounds which are relatively inert to microbial degradation (Gough et al., 1992). Biodegradation of UCM compounds by Pseudomonas aeriginosa was proven under laboratory conditions (Robson and Rowland, 1988). This bacterium is common in petroleum products and oil emulsions. The degradation rates were $n$-alkanes, $n$ alkenes $>$ highly branched alkenes $>$ highly branched alkanes + regular and tail-tail isoprenoid alkanes. A further study with $P$. fluorescens demonstrated that the UCM rate and extent of degradation was influenced by the molecular structure (Gough et al., 1992). However, the ability for oil hydrocarbon biodegradation is not extended. Chosson et al. (1991) showed that of 73 aerobic bacteria (Nocardia. Mycobacterium, Corynebacterium, Arthrobacter. Protoaminobacter, Pseudomonas, etc.), assessed for their ability to degrade steranes and cyclic triterpanes, only seven Gram-positive strains, belonging to the Nocardia, Mycobacterium and Arthrobacter genera, were able to produce noticeable effects. A Nocardia sp. produced the most extensive biodegradation, the preference observed being $\mathrm{C}_{27}>\mathrm{C}_{28}>\mathrm{C}_{29}$.

Refractory petroleum hydrocarbons (e.g. UCM compounds, triterpanes, steranes, etc.) are usually identified on the surface of building stones (SaizJimenez, 1993) and their degradation probably requires specific bacteria belonging to genera which are widespread in soils and well-known hydrocarbon degraders.

Polycyclic aromatic hydrocarbon-degrading bacteria have been used previously as indicators of the microbial activity in polluted environments. For instance, Bogardt and Hemmingsen (1992) detected and enumerated the phenanthrenedegrading bacteria in petroleum-contaminated sites; and phenanthrene-utilizing and phenanthrene-cometabolizing microorganisms have been evidenced in estuarine sediments (Cerniglia, 1993). For this reason, it was considered that these bacteria could be present on weathered stones, and a sampling was perfomed in the cathedrals of Mechelen (Belgium) and Seville (Spain).

Phenanthrene was readily mineralized to $\mathrm{CO}_{2}$ by the natural microflora in samples from the cathedrals (Fig. 3). Mineralization in some samples from the cathedral of Seville started rapidly with no apparent lag phase and reached a final extent of $35-27 \%$ of substrate mineralized after 100 days. In some cases, an acclimatization

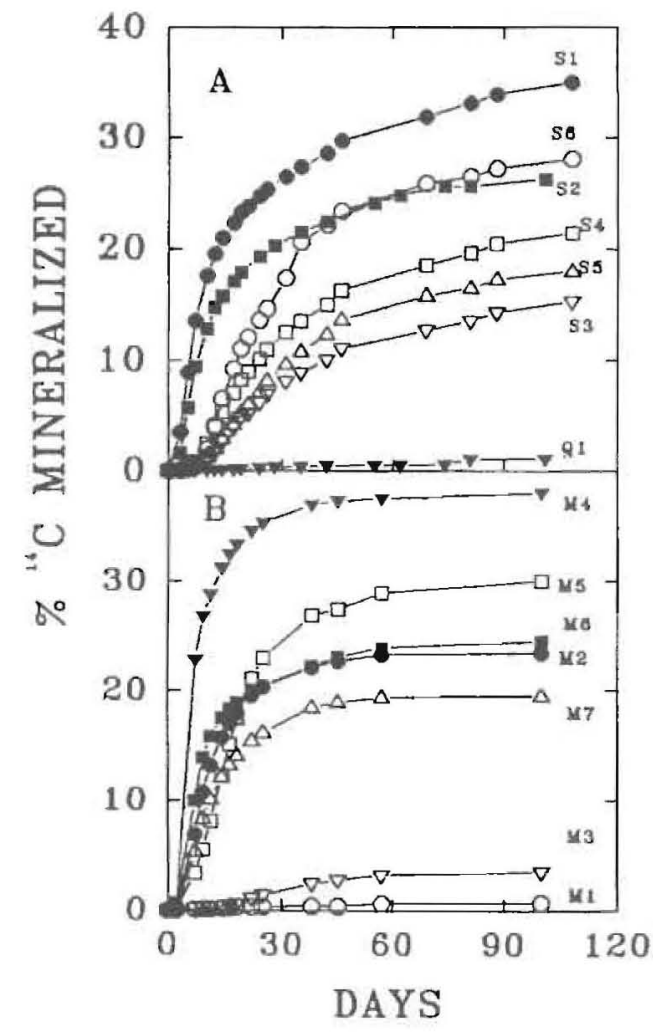

Fig. 3. Mineralization of phenanthrene in samples of weathered stones taken from Seville (A) and Mechelen (B) cathedrals. Samples S-1 to S-6 and M-1 to M-7 corresponded to different samplings in the cathedrals of Seville and Mechelen, respectively. Q-I is a sample taken. from a calcarenite quarry.

period of 10 days and a statistically lower rate and extent of mineralization characterized the mineralization in other samples, where only $15 \%$ of the compound was converted to $\mathrm{CO}_{2}$ in 100 days. Mineralization in samples from different places also occurred after an acclimatization period but differed in the rates and extents. In these samples the percentage of phenanthrene mineralized to $\mathrm{CO}_{2}$ in 100 days ranged from 18 to $28 \%$. A sample from a quarry showed a reduced activity close to background levels.

Bacteria able to grow with phenanthrene as the sole source of carbon were isolated from some stone samples, and included several Pseudomonas sp., Bacillus sp. and a (tentatively identified) Nocardia sp.

Bacillus sp., Pseudomonas sp. 1 and sp. 2, which showed the fastest growth, were tested for mineralization of phenanthrene in laboratory cultures. These bacteria mineralized phenanthrene in liquid culture at an initial concentration of $0.1 \mu \mathrm{g} \mathrm{ml}^{-1}$, both with and without stone samples. 


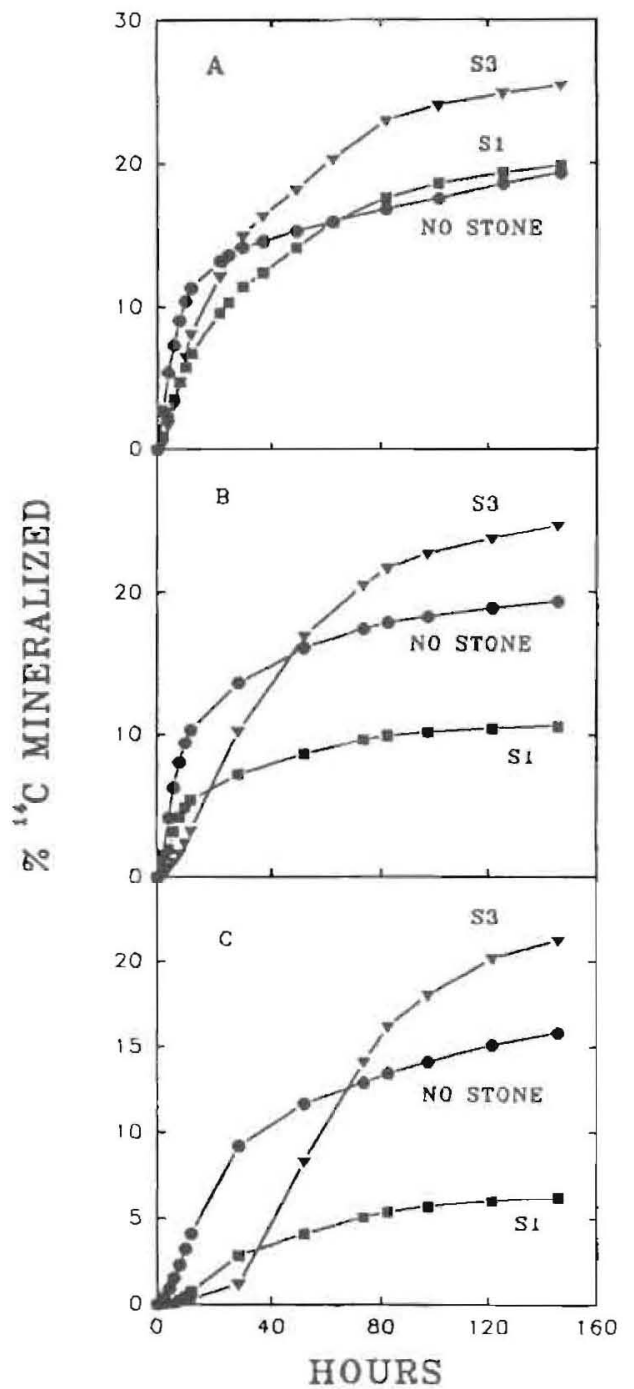

Fig. 4. Mineralization of phenanthrene by Bacillus sp. (A), Pseudomonas sp. 1 (B), and Pseudomonas sp. 2 (C), in liquid culture containing black crust (S-3), crust-free stone (S-1), or no stone.

The influence of stone samples on maximum rates of mineralization was different, depending on the isolate. Whereas Bacillus sp. mineralized the substrate at a maximum rate irrespective of whether the medium contained stone or not, the presence of stone induced different maximum rates of mineralization in the two Pseudomonas sp. Interestingly, the higher rate of mineralization for each Pseudomonas sp. strain occurred concomitantly with the presence of the type of stone from which it was isolated (Fig. 4).

The data reported indicate that microbial degradation of phenanthrene is common in weathered stones from European cathedrals. Although the experiments performed in this work required removal of the samples from the walls, the rapid and significant phenanthrene mineralization observed strongly suggests that microbial transformation reactions also occur in situ. Therefore, biological activity plays a role in the fate of organic compounds deposited on building stones located in polluted environments.

Mineralization of organic compounds is characteristic of growth-linked biodegradation and part of the phenanthrene is converted to cell components and degradation products that could remain in the stone. It is also possible that the particular conditions prevailing in the stone niches promote the selection of microorganisms able to transform, either by growth-linked reactions or by cometabolism, other anthropogenic compounds that have been so far considered as recalcitrant.

The data herein reported indicate that microorganisms are also able to remove some of the most abundant components of black crusts, such as gypsum and polycyclic aromatic hydrocarbons. Although the use of microorganisms is not foreseen as a method for cleaning façades due to some obvious limitations (dimension of monuments, time needed, wetting of weathered surfaces, economy, etc.), it must be emphasized that nature develops strategies for biodegradation of pollutants in urban environments. In fact, the continuous input of inorganic and organic compounds modifies the chemical composition of building stones, resulting in the selection of microorganisms with specific nutrient requirements or with a defined metabolic capability. Although we are still far from a complete understanding of the physiological diversity of microorganisms and their interactions in the surface of stone monuments, the biodegradation of deposited chemicals is envisaged as an important process in addition to biodeterioration.

\section{ACKNOWLEDGEMENTS}

This study was supported by the E.C., project EV5V-CT92-0112.

\section{REFERENCES}

Ariño, X., Ortega-Calvo, J. J., Hernandez-Marine, M. \& SaizJimenez, C. (1995) Effect of sulphur starvation on the morphology and ultrastructure of the cyanobacterium Gloeolhece PCC 6909. Archives of Microbiology 163,447-453. 
Bogardt, A. H. \& Hemmingsen, B. B. (1992) Enumeration of phenanthrene-degrading bacteria by an overlayer technique and its use in evaluation of petroleum-contaminated sites. Applied Environmental Microbiology 58, 2579-2582.

Bossert. I. and Bartha, R. (1984) The fate of petroleum in soil ecosystems. In Petroleum Microbiology, ed. R. M. Atlas. pp. 434-476. Macmillan Pub. Co., New York.

Cerniglia, C. E. (1993) Biodegradation of polycyclic aromatic hydrocarbons. Current Opinion in Biotechnology 4, 331338.

Chosson, P., Lanau, C., Connan, J. \& Dessort. D. (1991) Biodegradation of refractory hydrocarbons biomarkers from petroleum under laboratory conditions. Nature 351, 640-642.

Christwell, C. D., Ogawa, I., Tschetter, M. J. \& Markuszewski, R. (1988) Effect of hydrofluoric or hydrochloric acid pretreatment on the ultrasonic extraction of organic materials from ny ash for chromatographic analysis. Environmental Science Technology 22, 1506-1508.

De la Torre, M. A., Gomez-Alarcon, G., Melgarejo, P. \& SaizJimenez. C. (1991) Fungi in weathered sandstone from Salamanca cathedral, Spain. Science Total Environment $107,159-168$

Del Monte, M., Sabbioni, C. \& Vitori, O. (1981) Airborne carbon particles and marble deterioration. Atmosphere Environment 15, 645-652.

Gough, M. A., Rhead, M. M. \& Rowland, S. J. (1992) Biodegradation studies of unresolved complex mixtures of hydrocarbons: model UCM hydrocarbons and the aliphatic UCM in petroleum. Organic Geochemistry 1818, $17-22$.

Karpovich-Tate. N. \& Rebrikova, N. L. (I990) Microbial communities on damaged frescoes and building materials in the cathedral of the Nativity of the Virgin in the PafnutiiBorovskii monasteri, Russia. International Biodeterioration 27, 281-296.

Leahy, J. G. \& Colwell, R. R. (1990) Microbial degradation of hydrocarbons in the environment. Microbiology Review' 54, 305-315.

Lewis, F. J.. May, E. and Bravery, A. F. (1988) Metabolic activities of bacteria isolated from building stone and their relationship to stone decay. In Biodeterioration 7. eds D. R. Houghton, R. N. Smith \& H. O. W. Eggins, pp. 107-112. Elsevier Applied Science, London.

Nyns, E. J., Auquiere, J. P. \& Wiaux, A. L. (1968) Taxonomic value of the property of fungi to assimilate hydrocarbons. Antonie Leeuwenhoek 34, 441-457.

Ortega-Calvo, J. J., Hernandez-Marine, M. \& Saiz-Jimenez, C. (1991) Biodeterioration of buildings materials by cyanobacteria and algae. International Biodeterioration 28, $167-$ 187.

Ortega-Calvo, J. J., Sanchez-Castillo, P. M., HernandezMarine, M. \& Saiz-Jimenez, C. (1993) Isolation and characterization of epilithic chlorophyta and cyanobacteria from two Spanish cathedrals (Salamanca and Toledo). Nova Hedwigia 57, 239-253.

Ortega-Calvo, J. J., Ariño, X., Stal, L. J. \& Saiz-Jimenez, C. (1994) Cyanobacterial sulfate accumulation from black crust of a historic building. Geomicrobiology Journal 12, 15 22.

Ortega-Calvo, J. J. and Saiz-Jimenez, C. (1996) Polycyclic aromatic hydrocarbon-degrading bacteria in building stones. In 8ih International Congress on Deterioration and Conservation of Stone, ed. J. Riederer, Vol. 2, pp. 681-685.

Pctersen, K., Kuroczkin, J., Strzelczyk, A. B. and Krumbein,
W. E. (1988) Distribution and effects of fungi on, and in sandstones. In Biodeterioration 7. eds D. R. Houghton, R. N. Smith \& H. O. W. Eggins, pp. 455 460. Elsevier Applied Science, London.

Philp, R. P. (1985) Biological markers in fossil fuel production. Mass Spectrometry Review 4, 1-54.

Robson, J. N. \& Rowland, S. J. (1988) Biodegradation of highly branched isoprenoid hydrocarbons: a possible explanation of sedimentary abundance. Organic Geochemistry. 13, 691-695.

Saiz-Jimenez. C. (1984) Weathering and colonization of limestones in an urban environment. In Soil Biology and Conservation of the Biosphere, ed. J. Szegi, Vol. 2, pp. 757. 767. Akademiai Kiado, Budapest.

Saiz-Jimenez, C. (1991) Characterization of organic compounds in weathered stones. In Science. Technology and European Cultural Heritage, eds N. S. Baer. C. Sabbioni \& A. I. Sors, pp. 523-526. Butterworth-Heinemann, Oxford.

Saiz-Jimenez. C. (1993) Deposition of airborne organic pollutants on historic buildings. Atmosphere Environment 27B, 77-85.

Saiz-Jimenez, C. (1995) Deposition of anthropogenic compounds on monuments and their effect on airborne microorganisms. Aerobiologia 11, 161-175.

Saiz-Jimenez, C. and Bernier, F. (1981) Gypsum crusts on building stones. A scanning electron microscopy study. 6 th Triennial Meeting ICOM Committee for Conservation, Ottawa, paper $81 / 10 / 5,9$ pp.

Saiz-Jimenez, C. and Samson, R. A. (198I) Microorganisms and environmental pollution as deteriorating agents of the frescoes of Santa Maria de la Rabida, Huelva, Spain. 6th Triennial Meeting ICOM Committee for Conservation. Ottawa, paper $81 / 15 / 5,14$ pp.

Saiz-Jimenez, C.. Garcia-Rowe, J., Garcia del Cura, M. A. Ortega-Calvo, J. J., Roekens, E. \& Van Grieken. R. (1990) Endolithic cyanobacteria in Maastricht limestone. Science Total Environment 94, $209-220$.

Saiz-Jimenez, C., Hermosin, B., Ortega-Calvo, J. J. \& GomezAlarcon, G. (1991) Applications of analytical pyrolysis to the study of cultural properties. Journal of Analytical Applied Pyrolysis 20, 239-251.

Simoneit, B. R. T. (1985) Application of molecular marker analysis to vehicular exhaust for source reconciliations. International Journal of Environmensal Analytical Chemistry $22,203-233$.

Simoneit, B. R. T., Cox, R. E. \& Standley, L. J. (1988) Organic matter of the troposphere - IV. Lipids in Harmattan aerosols of Nigeria. Atmosphere Environment 22, 983-1004.

Standley, L. J. \& Simoneit, B. R. T. (1987) Characterization of extractable plant wax, resin and thermally matured components in smoke particles from prescribed bums. Environmental Science Technology 21, 163-169.

Tease, B. E., Jurgens, U. J. M., Golecki, J. R., Heinrich. U. R., Rippka, R. \& Weckesser. J. (1991) Fine structural and chemical analyses on inner and outer sheath of the cyanobacterium Gloeothece sp. PCC 6909. Antonie Leeuw'enhoek International Journal of General Molecular Microbiology' 59, 27-34

Warscheid, T., Oelting, M. \& Krumbein, W. E. (1991) Physico-chemical aspects of biodeterioration processes on rocks with special regard to organic pollutants. International Biodeterioration 28, 37-48.

Yu, M.-L. \& Hites, R. A. (1981) Identification of organic compounds on diesel engine soot. Analytical Chemistry 53, 951-954. 